$\begin{array}{r}\text { Volume and Issues Obtainable at Center for Sustainability Research and Consultancy } \\ \text { Sustainable Business and Society in Emerging Economies } \\ \text { ISSN: 2708-2172 \& (E): 2708-2504 } \\ \text { Volume 3: Issue 4 December 2021 } \\ \text { CSRᄃ } \\ \text { Journal homepage: www.publishing.globalcsrc.org/sbsee } \\ \hline\end{array}$

\title{
Role of Health Literacy in Shaping Consumer Organic Purchase Intention: A TPB- Based Perspective
}

Faiqa Kiran, Assistant Professor, Government College University, Faisalabad, Pakistan

*Muhammad Asim Nawaz, Assistant Professor, Government College University, Faisalabad, Pakistan

Naveed Akhtar Qureshi, Assistant Professor, Department of Business Administration,

Sukkur IBA University

Sumran Ali, PhD Candidate, Department of History of Science and Technology, University of Science and Technology of China, China, Hefei, Anhui.

*Corresponding author's email address: asimkahlon@gcuf.edu.pk

\begin{tabular}{l}
\hline ARTICLE DETAILS \\
\hline History \\
Revised format: Nov 2021 \\
Available Online: Dec 2021 \\
\hline Keywords \\
Health literacy, \\
Theory of planned behaviour \\
(TPB), \\
Attitude, Subjective norms, \\
Perceived Behavioral \\
Control, \\
Price elasticity
\end{tabular}

JEL Classification

$M 1, M 2$

Purpose: this study will examine the consumer intention to purchase the organic eatable items in the context of naïve organic market of Pakistan. Further, the study establishes the moderating role of price elasticity between TPB and consumer purchase intention.

Design/Methodology/Approach: 440 responses were obtained from the respondents. SEM (Structural Equation Modeling) engaged to study the measurement and structural model.

Findings: The organic attitude is a prime predictor of consumer purchase intention towards organic food products. In light of the theory of planned behaviour (TPB) study helps to understand the primary perspectives of consumer purchase intention of the organic food in the Pakistani market that is price sensitive.

Implications/Originality/Value: This study makes a theoretical contribution to the academics by enhancing the knowledge base in context of theory of planned behavior and practical contribution to the policymakers to shift the farmer focus towards the organic farming practices due to lucrative profit margins and at the same time working on the primary health knowledge to enhance the health-related literacy.

\section{OPEN $\rightarrow$ ACCESS}

(C) 2021 The authors, under a Creative Commons Attribution-

NonCommercial- 4.0

Recommended citation: Kiran, F., Nawaz, M. A., Qureshi, N.A. and Ali, S. (2021). Role of Health Literacy in Shaping Consumer Organic Purchase Intention: A TPB-Based Perspective. Sustainable Business and Society in Emerging Economies, 3 (4), 641-651

\section{Introduction}

The sustainable growth and consumption of food have gained significant attention in international politics and research. In past studies, humans' bad consumption choices are among the most vital contributors to health degradation (He, Breiting, \& Perez-cueto, 2012). But the present decade has seen a growing consciousness in the society for health protection. The ubiquitous nature of information traveling from the internet and social media has fueled the situation, and consumers are more concerned about intake quality 
(Hilverda, Kuttschreuter, \& Giebels, 2017). Considering health as an issue of importance for the survival of human beings, healthy consumerism has prospered (Michaelidou \& Hassan, 2008). This health concern developed from information gained from different sources to a paradigm shift in consumers' dietary choices in recent years. The "Organic Food" concept flushes fast as consumers consider it a healthier concept (Ryan \& Casidy, 2018). This phenomenon raises questions about modern agricultural production and stimulates the demand for organic foods (Nie et al., 2017). Organic food is defined as "food that is not genetically modified and produced in the natural habitat without the artificial support from chemicalbased pesticides and fertilizers (Chen, 2007). Consumers consider conventional food injurious to health, and organic is healthy, safe and less damaging to human health (C. Teng \& Lu, 2016).

So far, we have determined how consumers perceive and define health about organic food products is overlooked in studies regarded attitude to organic foods. It is astonishing as the concept of health in terms of organic food is considered absolute and out of ambiguity (Bisogni et al., 2012). As a result of how consumers understand healthiness and gain required information, not much research is done on this aspect. The literature illustrates that consumers who prefer organic food describe health and environment as an essential motive behind the choice, but there is also evidence that it's the health that drives the preference to an actual purchase decision that helps to move on from feeling that organic food is more expensive than the traditional food products (Witzel \& Zielke, 2017).

However, the current study is unique as it comprises the role of 'Health Literacy' as an external/environmental factor in the proposed persuasive psychological mode. Moreover, the moderating role of 'income elasticity' supports the author's claim about the uniqueness of the current study. Literature provides evidence that organic preference may not be the reason for purchase as price comparison is done against conventional food (Witzel \& Zielke, 2017). Organic food carries higher prices, it is worth studying health literacy alone. Similarly, availability is a concern, as organic is sold at a premium price, and consumers have to travel and find the product from a specific outlet (Scalco et al., 2017). This Study takes the data from underdeveloped nations to test the TPB-based framework and differences in the organic preferences.

\section{Literature Review}

The single model extensively applied in organic food purchasing intention, and other sustainable consumer behaviour is the Theory of planned behavior (TPB), e.g., (Lee \& Yun, 2015). TPB allows predicting consumer behavior, which three constructs can determine: Attitude, Subjective norm and perceived behavioral control. Attitude evaluates the cognitive part of behavior with a positive or negative outcome, Subjective norms investigate the behavioral evaluation done by others, and perceived behavioral control (PBC) studies the level of difficulty that a person has to face during performing behavior. Health literacy, defined as personal characteristics of the consumer to engage in a health evaluation would impact perception built based on these three factors. These factors make it essential how health-aware consumers respond to organic intentions.

The consumer is aware of harmful chemicals and artificially modified food products that hurt human health (Lee \& Yun, 2015). As an alternative to conventional food, organic food is gaining popularity. Raising awareness about organic stuff being friendly to human health adds to acceptability. Organic food free from contamination and human interference to increase growth is the obvious choice. At the same time, TPB's first construct is an attitude, defined as "the evaluative effect of positive or negative feelings of the individual in performing a particular behavior (Fishbein \& Ajzen, 1975). The prior experience and knowledge of specific products help to generate a positive attitude towards the purchase intentions (Suh et al., 2015). So, the study proposes that:

\section{H1a. Health literacy makes a positive contribution to attitude towards organic food.}

The second construct of theory is postulated as "the perceived easiness or difficulty of performing the 
behavior called perceived behavior control (PBC), and it is assumed to reflect experience as well as anticipated impediments and obstacles" (Ajzen, 1991). PBC is considered as personal assessment of the potential barriers and personal strength that influences the consumer intention to make purchase (Biel \& Thøgersen, 2007). The primary issue in final decision to buy the organic food is the price, brand and related trust along with the availability (Magnusson et al., 2001). Quality products come at some price, and many do not agree to pay a premium price for organic food (Millock \& Hansen, 2002). The aware consumer would behave less chance of being cheated. Health literacy can be a factor that fits in this gap and prepare the consumer to pay the extra price and travel the extra mile to concede the healthier food. Hence, we postulate that health literacy positively influences consumers' price and availability concerns.

H1b. Health literacy positively contributes to perceived behavioral controls (credence attribute \& availability).

The subjective norms are defined by (Ajzen \& Fishbein, 1977) as “the individual's perception of the likelihood that the potential referent group or individuals approve or disapprove of performing the given behavior." Specifically, it is the sum of consumer belief that how much essential others think they should or not perform a specific behavior, and consumer motivation to comply with those individuals (Aertsens et al., 2009). The foundation of social pressure is often described as reference groups, such as friends, family and peers (Aertsens et al., 2009). We assume that health literacy will positively contribute to overcoming negative social pressure not to perform a specific behavior. Organic food has credence attributes and is priced higher that might draw the consumer into the comparative situation with ordinary food products. So, we consider that:

\section{H1c. Health literacy makes a positive contribution to subjective norms.}

Previous literature highlights the attitude as a blend of both cognitive and affective elements. Cognitive in the form of cost and benefit comparison and affective as a positive or negative feeling. Both combine to form favorable or unfavorable attitudes towards organic products (Ajzen, 1991). Literature supports the influence of attitude and provides substantial empirical evidence. Such as a positive relationship between attitude and purchase intention of grocery products existed (Chen, 2007), similarly for halal food, organic and genetically modified food products (Spence \& Townsend, 2006). Thus, attitude is one of the strong predictors of consumer purchase intentions. So, we hypothesize as:

\section{H2: The attitude positively affects consumer intentions towards organic food.}

PBC is considered a barrier to performing the behavior, and in the context of this model, PBC refers to consumer perception of elements that may exert pressure to prevent behavioral performance (Prati et al., 2012). Literature have cited many factors that create hindrance to consumer motivation to purchase organic stuff (Schäfer \& Heinrich, 2015). Availability and credence attributes are two factors that need manufacturer and retailer attention. Availability is considered a barrier to purchase (Lea \& Worsley, 2005), but this issue is solved to some extent due to widened availability. Consumers claim that organic food is accessible at certain markets that require extra effort to purchase and organic food have shorter shelf life (Bryła, 2016). We consider that only health-aware consumers will put the extra mile to purchase organic stuff.

In the context of organic food, credence food can be the presence of harmful chemicals added during food items' production or processing stage. Research suggests that lack of knowledge and belief attributes of the organic product might create ambiguity, and putting extra effort to find organic products add to the situation. This implies that if consumers have difficulty in developing an understanding of organic stuff, it would be difficult for them to overcome the comparison with traditional stuff. So we state that: H3a: The Credence attributes (perceived behavioral control) significantly affect intention to purchase.

H3b: Easy accessibility (perceived behavioral control) has a significant positive effect on the intention to 
purchase.

(Ajzen, 1991) considered subjective norms as the pressure asserted by the society as hurdle in performing a certain set of behavior. The prior research substantiates the role of social gravity experienced by the individual while making food choices (Chang, 1998). Organic food has a general perception of being a healthier and better option (Tarkiainen \& Sundqvist, 2005). The approval or disapproval of the environmental circle in which consumer exist matters during decision-making process. Literature shows that subjective norms have significant influence on the consumer while making organic food assessments (Nie et al., 2017). Therefore, the study proposes that:

H4: The subjective norms make positive contribution to the purchase intentions of organic food.

Price elasticity is having moderating role between the TPB attributes and consumer purchase intention. The price elasticity of organic food is explained as the price difference between organic and ordinary eatable stuff (Bunte, Galen, Kuiper, \& Bakker, 2007). The price plays a significant role in consumer evaluation of a product. Price is the amount of money that a consumer has to bear for a transaction (Lichtenstein et al., 1993). In case of organic food price is higher as compared to conventional food products (Lichtenstein et al., 1993), means additional costs for buyers. Whereas, price is also perceived as quality symbol. A high price can lead to the favorable perception that price of the product is positively associated to the quality of product (Lichtenstein, et al., 1993). The studies show that consumer have higher quality perception regarding the organic food products in comparison to conventional food products (Aschemann-Witzel \& Zielke, 2017). So, it means that higher prices can have positive or negative effect on consumer intentions. So, the study offers four moderating role hypothesis as:

H5a: Price elasticity moderate positively between attitude and organic intentions.

H5b: Price elasticity moderate positively between credence attribute and organic intentions.

H5c: Price elasticity moderate positively between availability and organic intentions.

H5d: Price elasticity moderate positively between subjective norm and organic intentions.

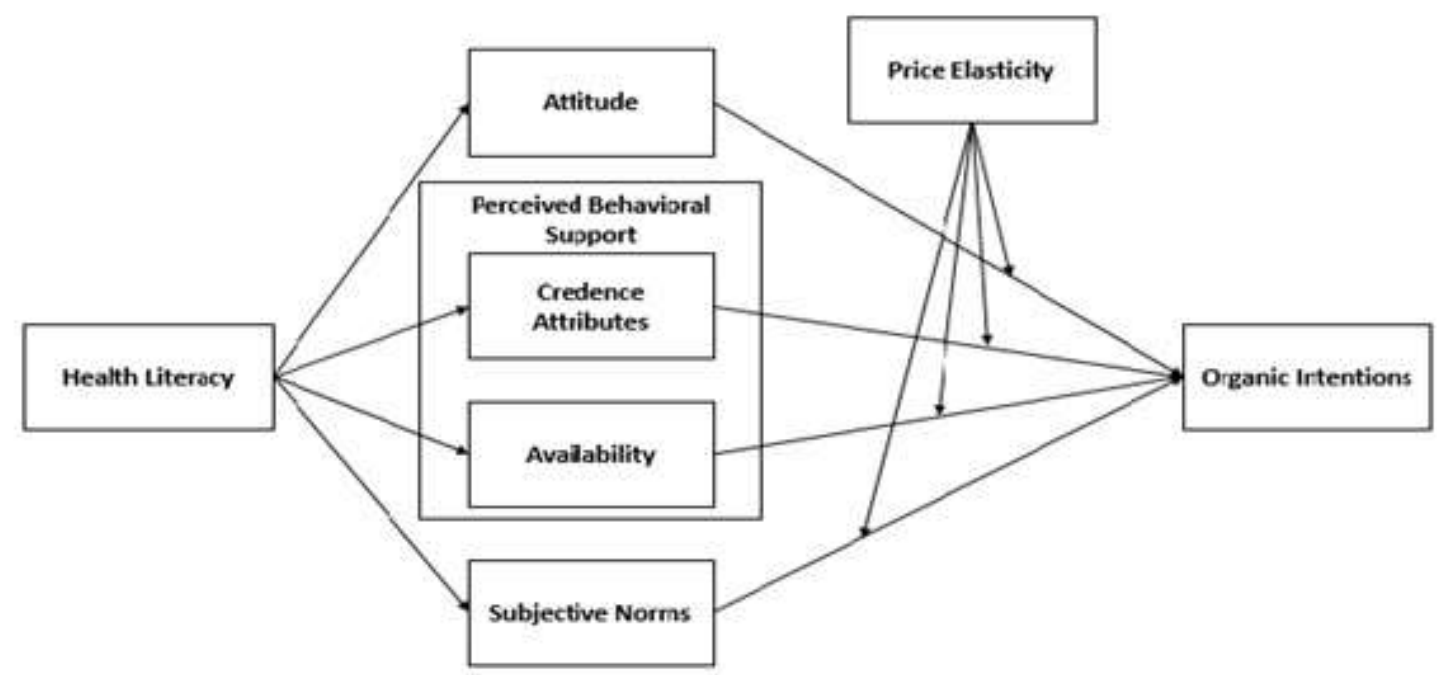

\section{Methodology}

Figure 1. Conceptual Framework

The data is gathered from the Federal and provincial capitals such as the Islamabad, Karachi, and Lahore. The data collection approach is quantitative in nature. The data is collected through the self-managed structured questionnaire-based survey from 12 different supermarkets located in the abovementioned cities having organic sale points. The respondent selection was done on the basis of visit to the organic shops of the market. Further, this study choose the convenience sampling method for the sake of data collection. 
The question constructs adapted from the previous body of literature to ensure the construct reliability and effectiveness. The questionnaire items of health literacy were adapted from the study of (von Wagner, Steptoe, Wolf, \& Wardle, 2009). The scale items of organic attitude were adapted from Aggestam et al. (2017) study. Further, the scale for perceived behavioral controls, namely credence attributes and availability, were taken from the study of (Ayyub et al., 2021) and (Erikson \& Eriksson, 2018). At the same time, scale items of subjective norms were adapted from the study of (Aggestam et al., 2017). In the end, the scale items of organic intention and price elasticity were adapted from the studies of (Asif, Xuhui, Nasiri, \& Ayyub, 2017) and (Lockie et al., 2004), respectively. The constructs item was measured with a 7point Likert scale. A sum of 453 questionnaires was given to the respondents, and 440 qualified for the further data analysis. 13 questionnaires were found having repetition of responses and few were having missing values. The data is collect in one go at the spot and have chances of data biasness and to ensure the data health this study uses series of test. First, Herman's one-factor test and found $23.21 \%$ variance that is lower than the standard value of $50 \%$. Second, the study uses the common latent factor technique along with the CFA based tool known as the marker variable (Podsakoff et al., 2011). These tests ensure that common method bias is not problematic for this study. The study framework is hypothesized as in figure 1 .

Table 1. Demographic profile of the respondents

\begin{tabular}{|c|c|c|c|}
\hline \multicolumn{2}{|c|}{ Demographics Profile } & \multirow{2}{*}{$\begin{array}{c}\text { Total } \\
440 \\
221\end{array}$} & \multirow{2}{*}{$\begin{array}{c}\% \\
100 \\
50.23 \\
\end{array}$} \\
\hline \multirow{2}{*}{ Gender } & Male & & \\
\hline & Female & 219 & 49.77 \\
\hline \multirow[t]{4}{*}{ Age group } & $18-24$ & 124 & 28.18 \\
\hline & $25-35$ & 167 & 37.95 \\
\hline & $36-45$ & 109 & 24.77 \\
\hline & $46-55$ & 40 & 9.09 \\
\hline \multirow[t]{4}{*}{ Education } & SSC & 75 & 17.04 \\
\hline & HSSC & 80 & 18.18 \\
\hline & University Graduate & 145 & 32.95 \\
\hline & Post Graduate & 140 & 31.81 \\
\hline \multirow{4}{*}{ Income } & $25000-45000$ & 25 & 5.68 \\
\hline & $46000-65000$ & 180 & 40.90 \\
\hline & $66000-85000$ & 200 & 45.45 \\
\hline & $85000-105000$ & 35 & 7.95 \\
\hline
\end{tabular}

\section{Analysis and Results}

The demographic profile of respondents reveals that almost half of respondents are females, with a percentage of $49.77 \%$ and $50.23 \%$. The survey participants' ages range between 18 to 55 years. Further, the income of respondents was between 25 thousand to 10500 thousand an amount. To ensure the convergent validity, the authors conduct reliability analysis, composite reliability, factor loading, VIF and Cronbach's alpha. The VIF measurement was observed and the minimum values were less then the standard value of 3.3 (Chang et al., 2010). Further, Cronbach's alpha all measurements were above the standard value of 0.70 (Hair et al., 1998). Similarly, 0.6 is the standard value of the composite reliability, and all values were higher than the cut-off minimum value (Bagozzi \& Youjae Yi, 1988). The AVE (average variance extracted) is considered to evaluate the discriminant validity and all the values were found higher than the minimum standard of 0.5 (Hair et al., 1998). The CFA (confirmatory factor analysis) results validates the internal consistency in term of factor loading as all values were above the 0.6 (Chin et al., 1997). Further, the model fit values were found above the threshold value recommended by the (Bagozzi \& Youjae Yi, 1988). Such as, GFI=0.912, AGFI=0.886, TLI=0.910, RMSEA=0.047, CFI=0.913. Table 2 presents the results in tabular form. 
Table 2: Reliability and validity results

\begin{tabular}{|c|c|c|c|c|c|c|}
\hline Construct & Item & VIF & FL & $\alpha$ & AVE & CR \\
\hline \multirow{4}{*}{$\begin{array}{c}\text { Health literacy } \\
\text { (HL) } \\
\text { (von Wagner, } \\
\text { Steptoe, Wolf, \& } \\
\text { Wardle, 2009) }\end{array}$} & HL1 & 1.41 & 0.810 & 0.869 & 0.611 & 0.801 \\
\hline & HL2 & 1.32 & 0.801 & & & \\
\hline & HL3 & 1.39 & 0.811 & & & \\
\hline & HL4 & 1.81 & 0.832 & & & \\
\hline \multirow{4}{*}{$\begin{array}{l}\text { Organic Attitude } \\
(\text { OA) } \\
\text { (Aggestam et al., } \\
\text { 2017) }\end{array}$} & OA1 & 2.12 & 0.801 & .0772 & 0.701 & 0.755 \\
\hline & OA2 & 2.01 & 0.751 & & & \\
\hline & OA3 & 2.10 & 0.732 & & & \\
\hline & OA4 & 1.98 & 0.701 & & & \\
\hline \multirow{3}{*}{$\begin{array}{c}\text { Credence Attributes } \\
\text { (CA) } \\
\text { (Ayyub et al., 2021) }\end{array}$} & CA1 & 1.41 & 0.700 & 0.822 & 0.722 & 0.888 \\
\hline & CA2 & 1.52 & 0.725 & & & \\
\hline & CA3 & 1.53 & 0.711 & & & \\
\hline \multirow{3}{*}{$\begin{array}{c}\text { Availability } \\
\text { (AL) } \\
\text { (Salzmann- } \\
\text { Erikson \& } \\
\text { Eriksson, 2018) }\end{array}$} & AL1 & 1.56 & 0.755 & 0.762 & 0.656 & 0.722 \\
\hline & AL2 & 1.99 & 0.751 & & & \\
\hline & AL3 & 2.3 & 0.761 & & & \\
\hline \multirow{3}{*}{$\begin{array}{c}\text { Subjective Norms } \\
\text { (SN) } \\
\text { (Aggestam et al., } \\
\text { 2017) }\end{array}$} & SN1 & 2.44 & 0.706 & 0.732 & 0.677 & 0.732 \\
\hline & SN2 & 2.66 & 0.705 & & & \\
\hline & SN3 & 2.76 & 0.770 & & & \\
\hline \multirow{4}{*}{$\begin{array}{c}\text { Intentions } \\
\text { (INT) } \\
\text { (Asif et al., 2017) }\end{array}$} & INT1 & 1.99 & 0.769 & 0.822 & 0.701 & 0.711 \\
\hline & INT2 & 1.93 & 0.777 & & & \\
\hline & INT3 & 1.83 & 0.732 & & & \\
\hline & INT4 & 1.56 & 0.811 & & & \\
\hline \multirow{3}{*}{$\begin{array}{c}\text { Price Elasticity } \\
\text { (PR) } \\
\text { (Lockie et al., 2004) }\end{array}$} & PR1 & 2.32 & 0.821 & 0.832 & 0.623 & 0.702 \\
\hline & PR2 & 2.22 & 0.833 & & & \\
\hline & PR3 & 2.17 & 0.756 & & & \\
\hline
\end{tabular}

After SEM analysis the estimation for the model fit were again found above the threshold value recommended by the Bagozzi \& Youjae Yi, (1988). The measurements were; GFI=0.922, AGFI=0.891, $\mathrm{TLI}=0.952, \mathrm{CFI}=0.980$ and $\mathrm{RMSEA}=0.045$. Further, the path coefficient results show that health literacy positively contribute to the all four perspectives of TPB. Health literacy makes positive contribution to the organic attitude, so $\mathrm{H} 1 \mathrm{a}$ is accepted $(\beta=0.211, \mathrm{p}<0.001)$. More health literacy makes positive contribution to perceived behavior controls (credence and availability), so H1b is accepted $(\beta=0.198$, $\mathrm{p}<0.001)$. H1c is also accepted $(\beta=0.178, \mathrm{p}<0.001)$, as health literacy contributes to the social pressures in term of subjective norms. Whereas, the attitude is positive contributor to consumer intentions for organic food, so $\mathrm{H} 2$ is supported $(\beta=0.220, \mathrm{p}<0.001)$. H3a and $\mathrm{H} 3 \mathrm{~b}$ are also supported $(\beta=0.201, \mathrm{p}<0.001)$ and $(\beta=0.169, p<0.001)$ respectively as they make positive contribution to the consumer intentions. Similarly, subjective norms also make positive contribution to the consumer intentions for organic food $(\beta=0.199, p<0.001)$. In last, the moderating role of price elasticity further strengthens the positive relationship between attitude, perceived behavioral controls and subjective norms. So, H5a $(\beta=0.183$, $\mathrm{p}<0.001), \mathrm{H} 5 \mathrm{~b}(\beta=0.175, \mathrm{p}<0.001), \mathrm{H} 5 \mathrm{c}(\beta=0.169, \mathrm{p}<0.001)$ and $\mathrm{H} 5 \mathrm{~d}(\beta=0.192, \mathrm{p}<0.001)$ are supported. The path coefficient results are given in table 3.

Table 3. The path coefficient results.

\begin{tabular}{lccc}
\hline Hyp. & Estimate & Significance & Result \\
\hline H1a & 0.211 & 0.001 & Supported \\
\hline H1b & 0.198 & 0.001 & Supported \\
\hline H1c & 0.178 & 0.001 & Supported \\
\hline H2 & 0.220 & 0.001 & Supported \\
\hline H3a & 0.201 & 0.001 & Supported \\
\hline
\end{tabular}




\begin{tabular}{llll}
\hline H3b & 0.169 & 0.001 & Supported \\
\hline H4 & 0.199 & 0.001 & Supported \\
\hline H5a & 0.183 & 0.001 & Supported \\
\hline H5b & 0.175 & 0.001 & Supported \\
\hline H5c & 0.169 & 0.001 & Supported \\
\hline H5d & 0.192 & 0.001 & Supported \\
\hline
\end{tabular}

\section{Discussion}

The current study finds that organic consumer with health literacy are keen observers and reader of the information revealed by the producer and retailer. Health literate consumer pay special consideration to information labeled regarding the product manufacturing and processing stages (Gracia \& de Magistris, 2008). The organic products feature few credence attributes that differentiate them from conventional products and revealed information help consumer to discriminate. These results support the find that credence features might make positive effect to consumer intentions in case buyer is good at health literacy. These findings are consistent to the previous finding of (Lee \& Yun, 2015) which found that credence attributes might positively influence the consumer intention when they have adequate knowledge of the products health benefits.

The exponential market growth of organic products led to wider distribution of organic products (Furneaux $\&$ Wade, 2011). But yet they are available at limited retail outlets or specified markets only (Bryła, 2016). Organic consumption requires extra effort to find and select desired organic products. Further, the consistent and choice availability concerns the consumer. The current results show that health literate consumer is more willing to put-in to gain access to the organic products considering allied health benefits. The Guntzviller et al., (2017), found that health literacy help consumer to overcome the differences like price and availability. Higher the literacy higher the potential to travel and search for organic products (Soones et al., 2017). Marketing literature widely recognizes the effective role of social circle in framing consumer intentions to purchase a certain product ( $\mathrm{Hu}$ et al., 2016). Health literate social circles will positively reinforce consumer intentions to make organic purchase (McCormack et al., 2017).

The organic purchase is gaining the social presence and society asserts the due share of pressure on the buyers to make the organic buying instead of the ordinary food items and the subjective norm is having highest value in context of this study. The organic food buyers exhibit the better decision making and behavior control is having positive relationship with the organic purchase. The adequate reason for such behavior can be nucleated family structure that provides more autonomy to the individuals in decision making. This relation is further strengthened by the available disposal income. In context of Pakistan, family system and lesser disposal income hinders the individual's decisional choices. These findings were quite different and also contradictory to prior literature (McCormack et al., 2017). The results further illustrate that the credence attributes were the significant predictors of consumer intentions than availability.

The interaction term of "price elasticity" make important contribution in enhancing and decreasing the consumer purchase intentions. In case of under developed and transitional states price elasticity performs differently compared to the developed nation. In Pakistani context, prevailing family system, that have centralized control in hands of family head and other members depend on the consumption choices of head (Asif et al., 2017). Price and willingness to pay is important consideration to make organic purchase for Pakistani consumers.

\section{Implications and Recommendations}

Health literacy can allow consumer to create intangible food value and positive feeling toward organic (Fenger et al., 2015). As the study focus on relationship between organic food and food consumption pattern, it provides both theoretical and managerial contribution. The current contributes theoretically by establishing the health literacy as important predictors of Attitude, subjective norms and PBC and moderating role of price elasticity. The past research work studies the casual relation of TPB and consumer 
intentions more or less ignoring the health literacy as predictor of TPB. Further, this study conducts a comparison of characteristics enhancing the motivation for organic consumption intention. Moreover, the managerial contribution guides the managers to design and implement the marketing strategy to develop the consumer knowledge about the organic food consumption, highlighting the potential benefits.

Additionally, the study act as path leader for the legislators to develop the organic cultivation, that will eventually benefit the health of ordinary consumer along with the environmental stability.

Moreover, organic cultivation and export lucrative business due to enhanced intention of paying more for organic stuff. Improved production and supply will help to meet the raising consumer demand. This for sure will lead to cut on premium prices of organic food that will bring in more consumers from middle class and under developed nations which can further improve the organic market share. Further on, this study clarifies the role of health literacy and related information revealed to consumer. The manufacturer and service providers can enhance the sales by making more and simplified disclosure of health-related information of organic food.

This study utilized limited research variables like the health literacy and related consumer intention variables, further studies can include organic literacy and other personality-based factors to improve the understanding of consumer intention. In last Pakistan was chosen for this investigation, future studies can make choices based on developmental and economical standing of other countries that have relatively rapid development of organic production and markets. However, further studies may perform such examination to other regions. Further, this study has collected the data at single time, future researchers can consider the longitudinal data collection techniques to enhance the validity of results.

\section{References}

Aertsens, J., Verbeke, W., Mondelaers, K., \& Van Huylenbroeck, G. (2009). Personal determinants of organic food consumption: a review. British Food Journal, 111(10), 1140-1167. https://doi.org/10.1108/00070700910992961

Aggestam, V., Fleiß, E., \& Posch, A. (2017a). Scaling-up short food supply chains ? A survey study on the drivers behind the intention of food producers. Journal of Rural Studies, 51, 64-72. https://doi.org/10.1016/j.jrurstud.2017.02.003

Aggestam, V., Fleiß, E., \& Posch, A. (2017b). Scaling-up short food supply chains ? A survey study on the drivers behind the intention of food producers. Journal of Rural Studies, 51, 64-72. https://doi.org/10.1016/j.jrurstud.2017.02.003

Ajzen, I. (1991). The theory of planned behavior. Organizational Behavior and Human Decision Processes, 50(2), 179-211. https://doi.org/10.1016/0749-5978(91)90020-T

Ajzen, I., \& Fishbein, M. (1977). Attitude-behavior relations: A theoretical analysis and review of empirical research. Psychological Bulletin, 84(5), 888-918. https://doi.org/10.1037/0033-2909.84.5.888

Amofa, F., Rachel, Y., Petrovici, D., \& Fearne, A. (2014). Towards a Framework for Understanding Fairtrade Purchase Intention in the Mainstream Environment of Supermarkets. https://doi.org/10.1007/s10551-0142509-9

Aschemann-Witzel, J., \& Zielke, S. (2017). Can’t Buy Me Green? A Review of Consumer Perceptions of and Behavior Toward the Price of Organic Food. Journal of Consumer Affairs, 51(1), 211-251. https://doi.org/10.1111/joca.12092

Asif, M., Xuhui, W., Nasiri, A., \& Ayyub, S. (2017). Determinant Factors Influencing Organic Food Purchase Intention and the Moderating Role of Awareness: A Comparative Analysis. Food Quality and Preference. https://doi.org/10.1016/j.foodqual.2017.08.006

Authors, F. (2009). Subjective norms, attitudes and intentions of Finnish consumers in buying organic food. https://doi.org/10.1108/00070700510629760

Ayyub, S., Asif, M., Open, M. N.-S., \& 2021, undefined. (2021). Drivers of organic food purchase intention in a developing country: the mediating role of trust. Journals.Sagepub.Com, 11(3). https://doi.org/10.1177/21582440211045076

Bagozzi, R. P., \& Youjae Yi. (1988). On the Evaluation of Structural Equation Models. Journal of the Academy of Marketing Science, 16(1), 74-94. https://doi.org/10.1177/009207038801600107

Biel, A., \& Thøgersen, J. (2007). Activation of social norms in social dilemmas: A review of the evidence and 
reflections on the implications for environmental behaviour. Journal of Economic Psychology, 28(1), 93112. https://doi.org/10.1016/J.JOEP.2006.03.003

Bisogni, C. A., Jastran, M., Seligson, M., \& Thompson, A. (2012). How People Interpret Healthy Eating: Contributions of Qualitative Research. Journal of Nutrition Education and Behavior, 44(4), $282-301$. https://doi.org/10.1016/J.JNEB.2011.11.009

Bonne, K., Vermeir, I., Bergeaud-Blackler, F., \& Verbeke, W. (2007). Determinants of halal meat consumption in France. British Food Journal, 109(5), 367-386. https://doi.org/10.1108/0070700710746786

Bryła, P. (2016). Organic food consumption in Poland: Motives and barriers. Appetite, 105, 737-746. https://doi.org/10.1016/j.appet.2016.07.012

Bunte, F., Galen, M. van, Kuiper, W., \& Bakker, J. (2007). Limits to growth in organic sales: Price elasticity of consumer demand for organic food in Dutch supermarkets.

Chang, M. K. (1998). Predicting Unethical Behavior: A Comparison of the Theory of Reasoned Action and the Theory of Planned Behavior. Journal of Business Ethics, 17(16), 1825-1834. https://doi.org/10.1023/A:1005721401993

Chang, S. J., van Witteloostuijn, A., \& Eden, L. (2010). From the Editors: Common method variance in international business research. In Journal of International Business Studies (Vol. 41, Issue 2, pp. 178-184). https://doi.org/10.1057/jibs.2009.88

Chen, M.-F. (2007). Consumer attitudes and purchase intentions in relation to organic foods in Taiwan: Moderating effects of food-related personality traits. Food Quality and Preference, 18(7), 1008-1021. https://doi.org/10.1016/J.FOODQUAL.2007.04.004

Chin, W. W., Gopal, A., Salisbury, W. D., \& David, W. (1997). Advancing the Theory of Adaptive Structuration: The Development of a Scale to Measure Faithfulness of Appropriation. Information System Research, 8(4), 342-367.

Fenger, M. H. J., Aschemann-Witzel, J., Hansen, F., \& Grunert, K. G. (2015). Delicious words - Assessing the impact of short storytelling messages on consumer preferences for variations of a new processed meat product. Food Quality and Preference, 41, 237-244. https://doi.org/10.1016/j.foodqual.2014.11.016

Fishbein, Martin., \& Ajzen, I. (1975). Belief, attitude, intention, and behavior : an introduction to theory and research. Addison-Wesley Pub. Co.

Furneaux, B., \& Wade, M. (2011). an Exploration of Organizational Level Information Systems Discontinuance Intentions. MIS Quarterly, 35(3), 573-598. https://doi.org/10.1016/j.infoandorg.2009.09.001

Gracia, A., \& de Magistris, T. (2008). The demand for organic foods in the South of Italy: A discrete choice model. Food Policy, 33(5), 386-396. https://doi.org/10.1016/j.foodpol.2007.12.002

Guntzviller, L. M., King, A. J., Jensen, J. D., \& Davis, L. A. (2017). Self-Efficacy, Health Literacy, and Nutrition and Exercise Behaviors in a Low-Income, Hispanic Population. Journal of Immigrant and Minority Health, 19(2), 489-493. https://doi.org/10.1007/s10903-016-0384-4

Hair, J., Black, W., Babin, B., Anderson, R., \& Tatham, R. (1998). Multivariate data analysis (5th ed.). Prentice Hall, Upper Saddle River, NJ.

He, C., Breiting, S., \& Perez-cueto, F. J. A. (2012). Effect of organic school meals to promote healthy diet in $11-$ 13 year old children . A mixed methods study in four Danish public schools q. Appetite, 59(3), 866-876. https://doi.org/10.1016/j.appet.2012.09.001

Hilverda, F., Kuttschreuter, M., \& Giebels, E. (2017). Social media mediated interaction with peers , experts and anonymous authors : Conversation partner and message framing effects on risk perception and sense-making of organic food. Food Quality and Preference, 56, 107-118. https://doi.org/10.1016/j.foodqual.2016.09.003

Hu, X., Huang, Q., Zhong, X., Davison, R. M., \& Zhao, D. (2016). The influence of peer characteristics and technical features of a social shopping website on a consumer's purchase intention. International Journal of Information Management, 36(6), 1218-1230. https://doi.org/10.1016/j.ijinfomgt.2016.08.005

Lee, H.-J., \& Yun, Z.-S. (2015). Consumers' perceptions of organic food attributes and cognitive and affective attitudes as determinants of their purchase intentions toward organic food. Food Quality and Preference, 39, 259-267. https://doi.org/10.1016/j.foodqual.2014.06.002

Lichtenstein, D. R., Ridgway, N. M., \& Netemeyer, R. G. (1993). Price Perceptions and Consumer Shopping Behavior: A Field Study. Journal of Marketing Research, 30(2), 234. https://doi.org/10.2307/3172830

Lockie, S., Lyons, K., Lawrence, G., \& Grice, J. (2004a). Choosing organics: A path analysis of factors underlying the selection of organic food among Australian consumers. Appetite, 43(2), 135-146. https://doi.org/10.1016/j.appet.2004.02.004

Lockie, S., Lyons, K., Lawrence, G., \& Grice, J. (2004b). Choosing organics: A path analysis of factors underlying the selection of organic food among Australian consumers. Appetite, 43(2), 135-146. 
https://doi.org/10.1016/j.appet.2004.02.004

Magnusson, M. K., Arvola, A., Koivisto Hursti, U., Åberg, L., \& Sjödén, P. (2001). Attitudes towards organic foods among Swedish consumers. British Food Journal, 103(3), 209-227.

https://doi.org/10.1108/00070700110386755

Marian, L., Chrysochou, P., Krystallis, A., \& Thøgersen, J. (2014). The role of price as a product attribute in the organic food context: An exploration based on actual purchase data. Food Quality and Preference, 37, 5260. https://doi.org/10.1016/j.foodqual.2014.05.001

McCormack, L., Thomas, V., Lewis, M. A., \& Rudd, R. (2017). Improving low health literacy and patient engagement: A social ecological approach. Patient Education and Counseling, 100(1), 8-13. https://doi.org/10.1016/J.PEC.2016.07.007

Michaelidou, N., \& Hassan, L. M. (2008). The role of health consciousness, food safety concern and ethical identity on attitudes and intentions towards organic food. International Journal of Consumer Studies, 32(2), 163-170. https://doi.org/10.1111/j.1470-6431.2007.00619.x

Millock, K., \& Hansen, L. G. (2002). Willingness to Pay for Organic Foods: A Comparison between Survey Data and Panel Data from Denmark.

Nie, Y. Y., Rong, A., Liang, D., \& Chen, D. J. (2017). Assessing the effect of organic-food short storytelling on consumer response. 2069(September). https://doi.org/10.1080/02642069.2017.1371143

Ozcaglar-Toulouse, N., Shiu, E., \& Shaw, D. (2006). In search of fair trade: ethical consumer decision making in France. International Journal of Consumer Studies, 30(5), 502-514. https://doi.org/10.1111/j.14706431.2006.00532.x

Podsakoff, P. M., MacKenzie, S. B., \& Podsakoff, N. P. (2011). Sources of Method Bias in Social Science Research and Recommendations on How to Control It. Http://Dx.Doi.Org/10.1146/Annurev-Psych-120710100452, 63, 539-569. https://doi.org/10.1146/ANNUREV-PSYCH-120710-100452

Prati, G., Pietrantoni, L., \& Zani, B. (2012). The prediction of intention to consume genetically modified food: Test of an integrated psychosocial model. Food Quality and Preference, 25(2), 163-170. https://doi.org/10.1016/J.FOODQUAL.2012.02.011

Rödiger, M., \& Hamm, U. (2015). How are organic food prices affecting consumer behaviour? A review. Food Quality and Preference, 43, 10-20. https://doi.org/10.1016/J.FOODQUAL.2015.02.002

Ryan, J., \& Casidy, R. (2018). Journal of Retailing and Consumer Services The role of brand reputation in organic food consumption : A behavioral reasoning perspective. Journal of Retailing and Consumer Services, 41(January), 239-247. https://doi.org/10.1016/j.jretconser.2018.01.002

Salzmann-Erikson, M., \& Eriksson, H. (2018). Absorbability, applicability and availability in nursing and care robots: A thematic analysis of Twitter postings. Telematics and Informatics, 35(5), 1553-1560. https://doi.org/10.1016/j.tele.2018.04.001

Scalco, A., Noventa, S., Sartori, R., \& Ceschi, A. (2017). Predicting organic food consumption: A meta-analytic structural equation model based on the theory of planned behavior. Appetite. https://doi.org/10.1016/j.appet.2017.02.007

Schäfer, D. B., \& Heinrich, D. (2015). Green Branding: Do Local and Global Brands Benefit from Organic Labeling. In The Sustainable Global Marketplace (pp. 443-443). Springer International Publishing. https://doi.org/10.1007/978-3-319-10873-5_258

Shaw, D., \& Shiu, E. (2003). Ethics in consumer choice: a multivariate modelling approach. European Journal of Marketing, 37(10), 1485-1498. https://doi.org/10.1108/03090560310487202

Soones, T. N., Lin, J. L., Wolf, M. S., O’Conor, R., Martynenko, M., Wisnivesky, J. P., \& Federman, A. D. (2017). Pathways linking health literacy, health beliefs, and cognition to medication adherence in older adults with asthma. Journal of Allergy and Clinical Immunology, 139(3), 804-809. https://doi.org/10.1016/J.JACI.2016.05.043

Spence, A., \& Townsend, E. (2006). Examining Consumer Behavior Toward Genetically Modified (GM) Food in Britain. Risk Analysis, 26(3), 657-670. https://doi.org/10.1111/j.1539-6924.2006.00777.x

Suh, B. W., Eves, A., Lumbers, M., Service, F., Management, A., Lumbers, M., Service, F., \& Management, A. (2015). DEVELOPING A MODEL OF ORGANIC FOOD CHOICE BEHAVIOR. Social Behavior and Personality: An International Journal, 43(2), 217-230. https://doi.org/10.2224/sbp.2015.43.2.217

Tarkiainen, A., \& Sundqvist, S. (2005). Subjective norms, attitudes and intentions of Finnish consumers in buying organic food. British Food Journal, 107(11), 808-822. https://doi.org/10.1108/00070700510629760

Teng, C., \& Lu, C. (2016). Organic food consumption in Taiwan : Motives , involvement , and purchase intention under the moderating role of uncertainty. Appetite, 105, 95-105. https://doi.org/10.1016/j.appet.2016.05.006

Teng, C.-C., \& Wang, Y.-M. (2015). Decisional factors driving organic food consumption. British Food Journal, 
117(3), 1066-1081. https://doi.org/10.1108/BFJ-12-2013-0361

Vitters $\emptyset$, G., \& Tangeland, T. (2015). The role of consumers in transitions towards sustainable food consumption. The case of organic food in Norway. Journal of Cleaner Production, 92, 91-99. https://doi.org/10.1016/J.JCLEPRO.2014.12.055

von Wagner, C., Steptoe, A., Wolf, M. S., \& Wardle, J. (2009). Health literacy and health actions: A review and a framework from health psychology. Health Education and Behavior, 36(5), 860-877. https://doi.org/10.1177/1090198108322819

Yazdanpanah, M., \& Forouzani, M. (2015). Application of the Theory of Planned Behaviour to predict Iranian students' intention to purchase organic food. Journal of Cleaner Production.

https://doi.org/10.1016/j.jclepro.2015.02.071 